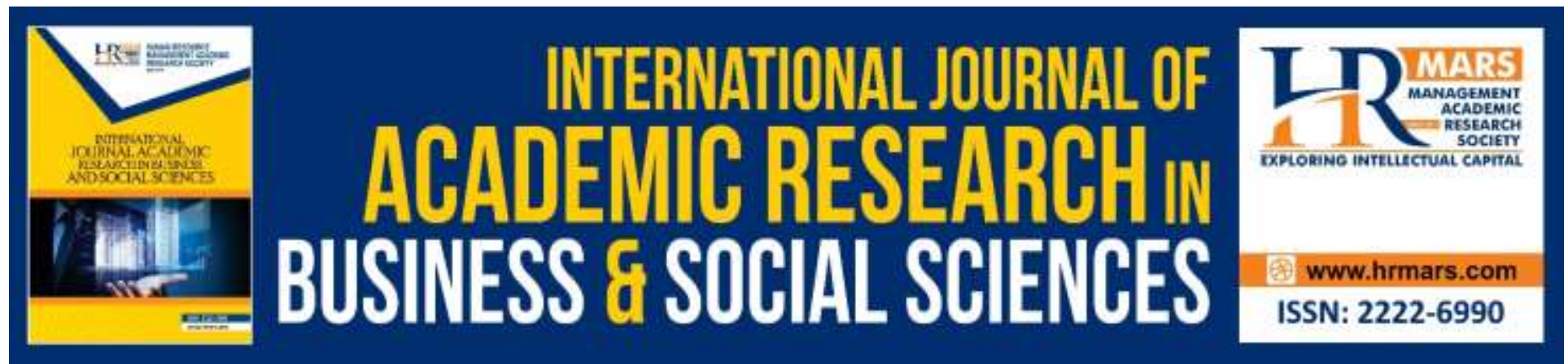

\title{
Food Waste Management in Coastal Hotels in Tanzania
}

\author{
Mary Shija Maduhu, Francis Makori
}

To Link this Article: http://dx.doi.org/10.6007/IJARBSS/v9-i11/6541

DOI: 10.6007/IJARBSS/v9-i11/6541

Received: 11 October 2019, Revised: 30 October 2019, Accepted: 03 November 2019

Published Online: 13 November 2019

In-Text Citation: (Ling et al, 2019)

To Cite this Article: Maduhu, M. S., Makori, F. (2019). Food Waste Management in Coastal Hotels in Tanzania. International Journal of Academic Research in Business and Social Sciences, 9(11), 185-204.

Copyright: (C) 2019 The Author(s)

Published by Human Resource Management Academic Research Society (www.hrmars.com)

This article is published under the Creative Commons Attribution (CC BY 4.0) license. Anyone may reproduce, distribute, translate and create derivative works of this article (for both commercial and non-commercial purposes), subject to full attribution to the original publication and authors. The full terms of this license may be seen at: http://creativecommons.org/licences/by/4.0/legalcode

Vol. 9, No. 11, 2019, Pg. 185 - 204

Full Terms \& Conditions of access and use can be found at http://hrmars.com/index.php/pages/detail/publication-ethics 


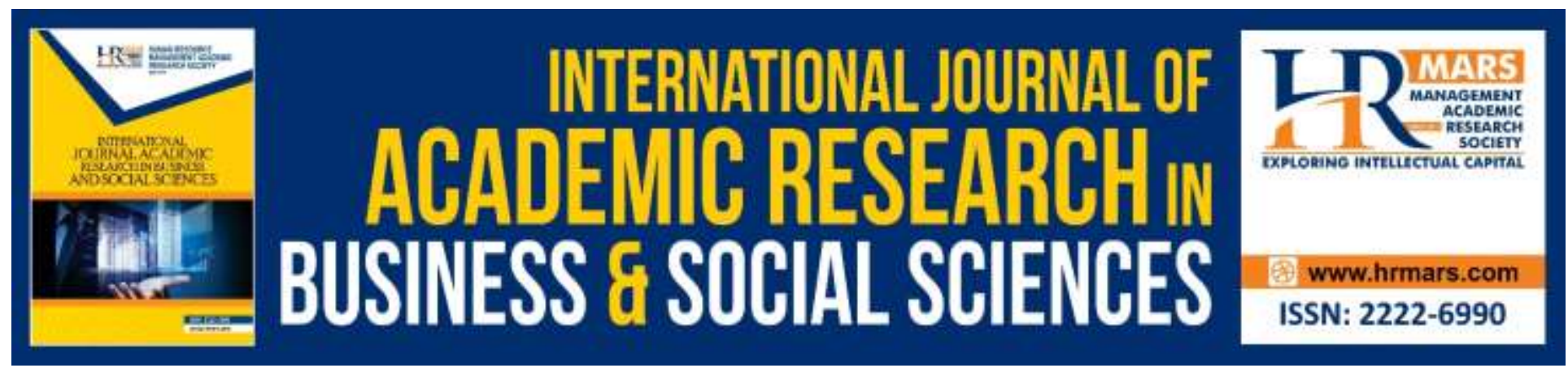

\title{
Food Waste Management in Coastal Hotels in Tanzania
}

\author{
Mary Shija Maduhu, Francis Makori \\ National College of Tourism \\ Email: maryshija68@yahoo.com
}

\begin{abstract}
This paper intends to present an overview of current practice in food waste management and problem associated with improper waste Management. Hotels industry in Tanzania, in recent years, has been a major consistent force behind the tremendous growth in GDP. However, hotels are major consumers of resources hence contribute heavily towards the waste generation, as compared to others. The New trend of Go green strategies like recycling or convert waste in another economical way can provide a great benefit to hotel industry not only in Coastal hotels but the country at large. While there has been some research on environment sustainability in the Hospitality and Tourism Industry in Tanzania and elsewhere, the issue of food waste Management in Coastal Hotels has not identified the best Practice in food waste management. Presently, there are improper waste management practices in Hotel industry. The main objective of the study was to identify opportunities and challenges of food waste management in coastal hotels in Tanzania. The research used both qualitative and quantitative methods whereas data were analyzed by statistical package for social sciences (SPSS), data collection was done through interviews and structured questionnaires. Interviews involved Coastal hotels from three different locations namely Dar es Salaam, Zanzibar and Tanga regions in Tanzania with a sample of 100 respondents. The findings in this research are optimistic to address the proper management of food waste which can lead to higher profitability for hotel and save environmental pollution. Lastly the researcher recommended for the Government, hotel stakeholders and individuals as a whole to be more creative and innovative to come up with different methodologies on how they can change these food waste challenges to be opportunities so as to reduce and manage waste for the conducing environment.
\end{abstract}

\section{Introduction}

Solid Waste Management is among of the most economic and environmental challenges in Tanzania. It is estimated that the quantity of Municipal Solid Waste generated countrywide amounts to more than 10,000 tons per day (NESR, 2017). The situation is aggravated by rapid growth of population. The estimated 2019 population of Tanzania is 58.01 million, up from the 2014 estimate of 50.8 million, ranking 25th in the world (World Population Review, 2019). There is a tremendous growth of population in urban than rural areas, many people move to urban area because they attracted by various economic activities thus making urban environment most 
privileged for investment and employment. This increase of population also attracts many to invest in hotel and tourism sector. It is estimated that over 219,000 people derive their livelihoods and earnings from tourism related activities as opposed to primary products (Bergqvist, 2006).

WTTC indicates that the direct contribution of Travel \& Tourism in Tanzania to GDP in 2016 was TZS 4,585.5 billion (4.7\% of GDP). This is forecast to rise by $3.7 \%$ to TZS 4,755.2 billion in 2017. This primarily reflects the economic activity generated by industries such as hotels, travel agents, airlines and other passenger transportation services (excluding commuter services). But it also includes the activities of the restaurant and leisure industries directly supported by tourists. The direct contribution of Travel \& Tourism to GDP is expected to grow by $6.8 \%$ per annum to TZS $9,192.3$ billion (4.7\% of GDP) by 2027 . Although hotels do not create huge amount of wastes and consume huge amount of resources individually, collectively they cause substantial impacts on the environment. It has been estimated that $75 \%$ of hotels' environmental impacts are directly associated with excessive consumption. This is wasteful in terms of resources and it increases operational costs unnecessarily. It is economically beneficial for hotels to pursue "green practices" in three areas, namely energy saving, water conservation, recycling and waste management. Public awareness of environmental issues is growing around the world, and the environmental profile of a hotel or a restaurant forms an increasingly important part of its overall reputation.

Since colonial era, solid waste management in urban areas has been regarded as a public goods and services where by the Government has the duty to provide the Solid Waste Management services. In order to handle this government formed different legislations for the service of managing waste. The Environment Management Act (EMA) of 2004 is the umbrella law on environment management in Tanzania. Section 114 (1), 118 and 119 of the Act stipulates the duty of local government authorities in managing and minimizing solid waste. It provides for the existence of the National Environment Management Council (NEMC).

Other legislations governing municipal solid waste management includes; Environment (Solid Waste Management) Regulations, of 2009; which applies to all matters pertaining to Solid waste and the Environment Management (Hazardous Waste Control) Regulations of 2009 which applies to all categories of hazardous wastes, including e-waste for which currently there is no specific policy/regulations.

However, due to rapid urban growth coupled with scarcity of funds, many urban authorities are facing and reluctance of the urban dwellers to pay for the services represents a phenomenal challenges. This paper is therefore intended to present an overview of current practices in food waste management and problem associated with improper waste Management. While there has been some research on environment sustainability in the Hospitality and Tourism Industry in Tanzania and elsewhere, the issue of food waste Management in coastal hotels has not identified the best practice in food waste management. Presently, there are improper waste management practices in Hotel industry.

\section{Literature Review}

\section{Concept of Waste and Food Waste}

Waste as it was defined by Michael-Agwuoke (2012) is a residual material which is as a results of human activities which cannot be re used or recovered as a source, recycled into material 
production processes. (OECD, 2003), (UN Statistics Division, 2011) defined waste as materials that are not prime products (that is, products produced for the market) for which the generator has no further use in terms of his/ her own purpose of production, transformations or consumption and of which he/she wants to dispose. Waste can be characterized in different forms. Some common characteristics used in the classification of waste includes the physical states, physical properties, reusable potentials, biodegradable potentials, source of production and the degree of environmental impact (Demirbas, 2011; Dixon \& Jones, 2005; White et al., 1995). White et al. (1995) stated that waste can be classified broadly into three main types according to their physical states; these are liquid, solid and gaseous waste. Solid waste is that wastes produced by human activities, and can be in a solid or semisolid form and are thrown away as useless products (Tchobanoglous, et al. 1993).

Basu (2010) argued that, solid waste includes municipal waste, some biomedical waste, electronic waste and some hazardous waste. Basu stated that solid waste could be putrescible and non-putrescible. Similarly, Kaseva \& Gupta (1996) noted that solid wastes are waste materials from municipal, industrial and agricultural activities. Tchobanoglous et al. (1993) concluded that unlike other wastes, solid wastes do not disappear easily. They argued that, where solid waste is thrown today is where they will still be found in future. Dixon \& Jones (2005) reported that, the compositions of municipal solid include materials such as soil, garden and food waste, wood, paper, ashes, plastics, textiles and rubber. They concluded that, municipal solid wastes area collection of wastes that are mainly from household and commercial sources.

Similarly, Buah et al. (2007) added that, Municipal Solid Waste mainly consist of food and garden waste, textiles, paper or cardboard, plastics, glass and metals. They argued that, due to the composition of Municipal Solid Waste, the waste could easily be used for energy recovery or the production of fuel. Commercial solid wastes are solid or semi-solid wastes produced as a result of activities in stores, restaurants, markets, offices, hotels, motels, print shops, service stations, auto repair shops among others (Tchobanoglous, 1993). Due to the limited scope of the research study, other forms of wastes are excluded. Only food waste will be discussed in detail leaving the open room for further researches to be conducted concerning other forms of wastes.

Food waste is defined as organic waste that has its origin in food, or in inputs into food production (Food Wise Hong Kong Campaign, 2013). Food that is disposed of as waste can be divided into: (1) avoidable/edible food waste, such as slices of bread, cooked vegetables, or salads, or any kind of food that at some point was edible before disposal (Food Wise Hong Kong Campaign, 2013); and (2) unavoidable food waste, which is the food that is non edible from preparation to consumption, such as egg shells or bones (Bruns-Smith et al., 2015).Food waste can be categorized into two groups; before it is consumed (pre-consumer food waste) which is the food waste produced from food leftovers and food which is spoiled before preparation or the one which is rotten. The other type is food waste after consumption (post-consumer food waste) or sometimes is called plate waste, this is the food served to the guests that have not been eaten (food items left or discarded by the customers) (2016, in Cuglin, Petljak and Naletina 2017, 538), (Shakman, 2013). 
Figure: 1. Classification of Food and Drink Waste Relating To the Possibility of Mitigating Their Production

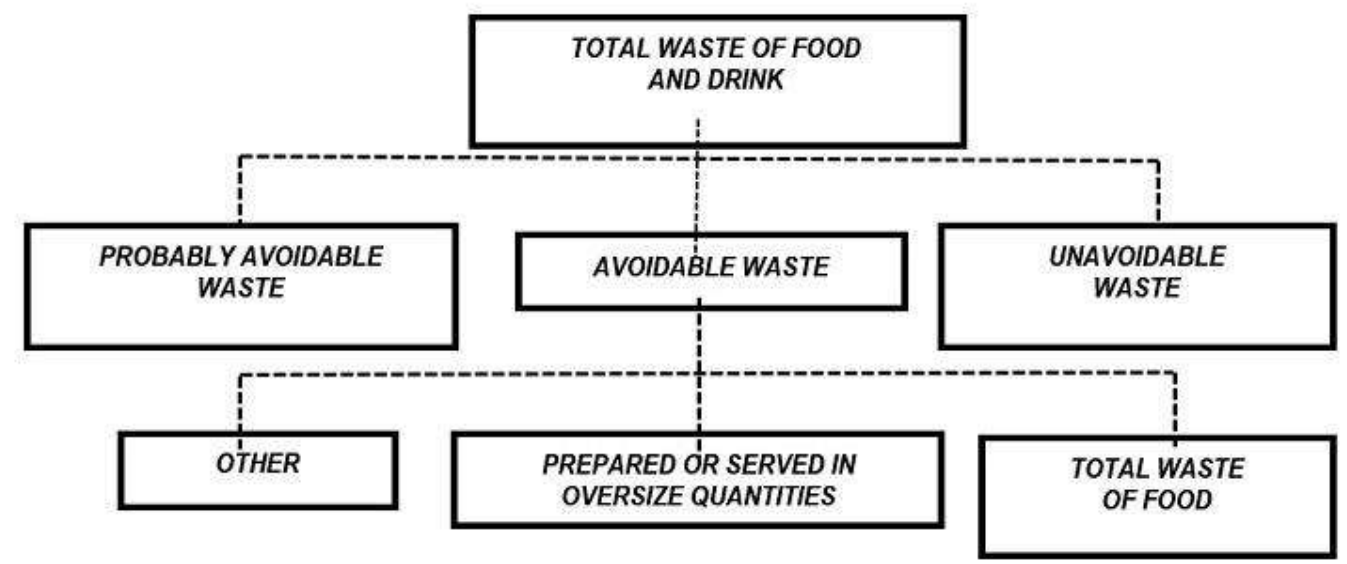

Source: Voća (2014:8)

Source: Cuglin, Petljak, \& Naletina, (2017: 539)

\section{Food waste in Hotel Industry}

Hotels are the massive producer of waste. Curry (2012) writes in his study that almost 50 percent of total waste of hotel industry comes from the food waste. Being one of the largest food consumers, hotels generate a large amount of food waste every day (Pariatamby \& Periaiah, 2007; Papargyropoulou et al., 2016; Sandaruwani \& Gnanapala, 2016). WRAP (2011) found that almost $50 \%$ of food waste produced from total solid waste was generated by the hotel industry. The generation of this waste and managing it is not only a financial problem but environmental problem too. Bruns-Smith, Choy, Chong and Verma (2015) concur, arguing that the hotel industry is known as the most environmentally harmful hospitality sector.

In the process of delivering best services and achieving profits, the industry is forced to provide with high quality and quantity of food portions to survive the competition which is ultimately going to waste as producing high quality food for presentation and taste, large amount of food is wasted in the process and in the same way when the customer leaves the plate due to high portion or any other reason food is again put to waste (Singh \& Amandeep, 2018). Food waste is said to be one of the main contributors to the carbon emission of hotels (Remolador, 2011) and, hence, its management requires critical attention to be paid to greater hotel greening (Griffith, Jackson \& Lues, 2017). Since there are various steps where food waste is generated there is cost involved such as disposal and transport of waste and labor costs. The hotel industry needs to look into efficient ways which can bring savings to cost incurred and help in waste management (Singh \& Amandeep, 2018).

\section{Causes of Food Wastes in Hotels}

Different previous scholars have showed that there is a difference between food loss and food waste. It is pointed out that food loss means the decrease in food mass or in its quality (FAO, 2014, in Cuglin, Petljak, and Naletina, 2017) or sometimes food loss consists of food spills, spoils, incurs an abnormal reduction in quality such as bruising or get lost before it reaches the 
customers. Food loss usually occurs at the production, storage, processing, and distribution stages in the food value chain (Lipinski, 2013). On the other hand food waste tends to be food that has fine quality and is suitable for consumption, but does not get consumed because it gets discarded-either before or after it is left to perish (Linh, 2018). Also Linh (2018) added that Food waste typically takes place at the retail and consumption stages in the food value chain. The cause can be the negligence or a conscious decision to throw food away. (Linh, 2018) stated that although both food loss and waste happen all over the world, food loss tends to be more prevalent in developing countries, while food waste tends to be more prevalent in developed countries. As the drivers that generate food waste and the solutions to it are different from those of food losses, food waste is recognized as a distinct part of food loss (FAO, 2017)

Various studies has indicated that food waste occur at different stages of the food chain from the supply to the after-service. According to (Baldwin \& Shakman, 2012, 58-59), pre-consumer food waste is often caused by the number of reasons stated in Table below. This table below is the summary of the main causes of food waste in the hospitality industry introduced by Baldwin and Shakman in the book "Greening Food and Beverage Services". The causes are categorized into two types: pre-consumer and post-consumer. (Baldwin \& Shakman, 2012, 58-59).

\section{Table: 1. Causes of Pre-Consumer and Post-Consumer Food Waste}

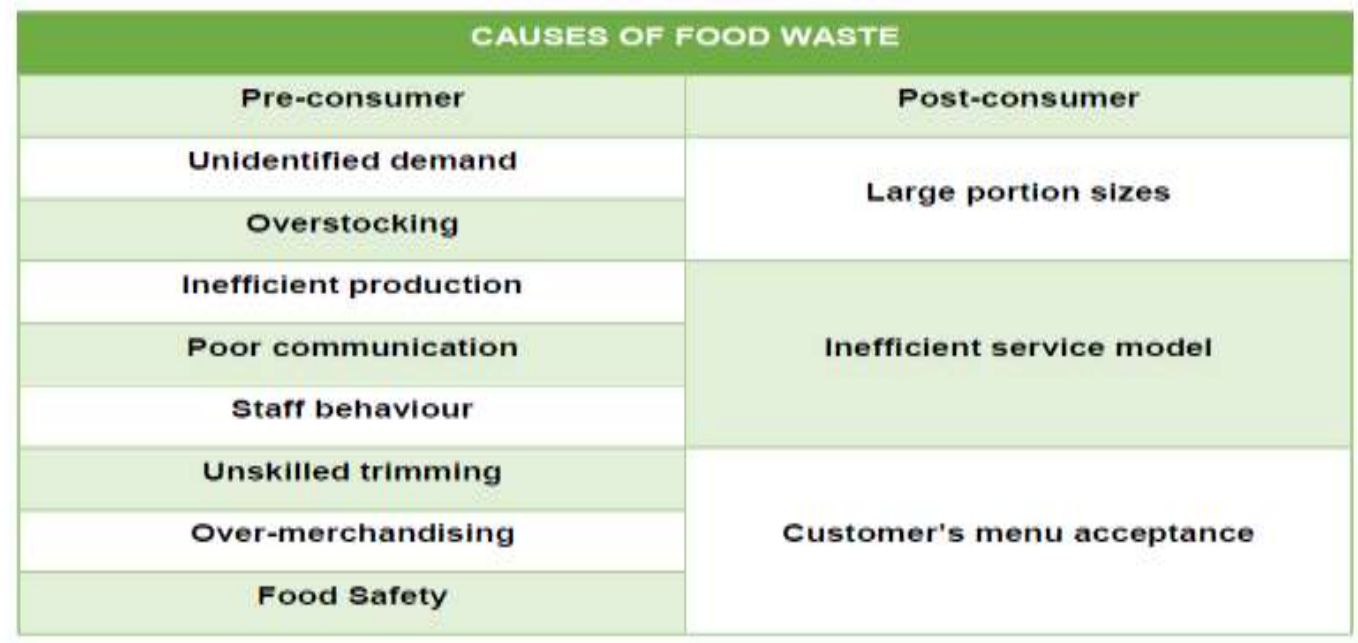

Source: Baldwin \& Shakman, (2012)

Hogan (2016) categorized the cause of food waste according to the stages. According to him most five common food waste caused by the following five factors which are; over-production, food safety, too many customers' options, over merchandise and false labour/was trade-off. Another study points out that the causes of food waste come from different stages in the supply chain such as improper storage of raw material or products, sloppy transportation or improper preservation leading to expiration, etc. (Parfitt, 2010, in Cuglin, Petljak, \&Naletina, 2017, 540). These causes are illustrated through this following figure: 
Figure: 2. Critical Points of Food Waste In the Supply Chain Cuglin, Petljak, \&Naletina, (2017:540)

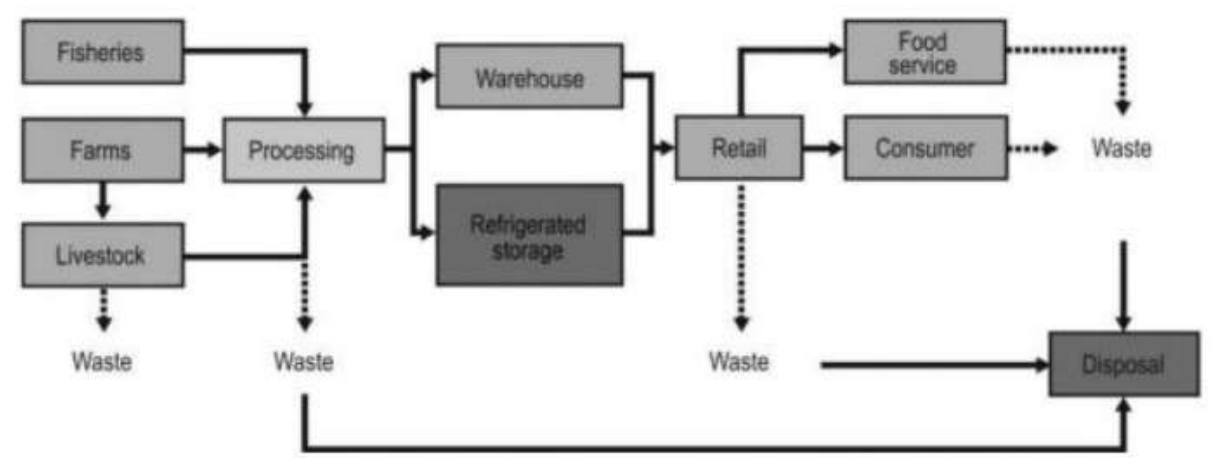

\section{Challenges of reducing Food Waste in the Hotel Industry}

Food waste requires thoughtful administrations, yet, it is true that handling food waste in food service industry is easier said than done due to the fact that there still remain many obstacles. In America, a total of 34 million tons of food waste was generated in 2009 (14\% of the country's total waste stream (Sitton, 2011). He also added that only less than $3 \%$ of food waste was able to be recovered for reuse and recycling in 2009. Various factors such as the differences in the number of service locations, type and amount of food discarded and distances from food recycling facilities put food service operators in a dilemma over how to tackle food waste disposal (Linh, 2018). Food Safety Law, service type, consumer behaviors and chefs lacking experience are mentioned as few challenges facing food waste reduction (Linh, 2018). Habit is likely to play an important role in the practices and behaviors relating to food waste in hotels/restaurants. As highlighted by Darnton (2008), both waste behaviors and food choice have a strong habitual element, given their frequency and automaticity. People, including guests, can be very impressionable when it comes to how much they choose to eat. The flexible range as to how much food an individual can eat (Herman \& Polivy, 1984) encompasses the potential often to eat more than was originally intended (Berry, Beatty \& Klesges, 1985).

Best Practices on Food Waste management

Demirbas (2011) describes waste management as a process by which wastes are gathered, transported and processed before disposal of any remaining residues. Evidently, it is known that a large part of the food waste in the food supply chain occurs at the retail and consumption stage, especially in food service enterprises (restaurants, cafeterias, fast food and catering services) (, 2007; Parfitt, Barthel and Macnaughton, 2010, p. 3065; Gunders, 2012, p. 10-11). Similarly, the hospitality industry, which represents one-third of the total food consumption in the world (Marthinsen, Kaysen and Kirkevaag, 2012, p. 15), and the hotel businesses that have a large amount of hospitality capacity especially in international respect are areas of significant food waste and losses (Omidiani and HashemiHezaveh, 2016, p. 670). Waste management has thus become a key priority, referring to all the activities related to avoiding, reducing or recycling waste, throughout the production and consumption chain (Papargyropoulou et al., 2016). Government can play part also by involving NGOs and other corporations to start different movements on arguing with retailers and wholesalers not to sell imperfect-looking products or 
INTERNATIONAL JOURNAL OF ACADEMIC RESEARCH IN BUSINESS AND SOCIAL SCIENCES Vol. 9, No. 11, November, 2019, E-ISSN: 2222-6990 @ 2019 HRMARS

products which had been close to their use-by-date, educating consumers by cooking books, workshops at schools (Ocicka \& Raźniewska, 2018). Government may also engage itself on preparing different forum movement. In 2000 the UK government founded the Waste \& Resources Action Programme (WRAP) to promote sustainable waste management. Its campaign, called "Love Food, Hate Waste" launched in 2007, is focused on educating individual consumers and changing their habits in everyday food waste reduction actions (Ocicka \& Raźniewska, 2018).

Troschinetz \& Mihelcic (2009) pointed out that some waste management methods are often preferred than others. For instance, reuse, recycling, composting and energy generation from incineration are often preferred to landfills. However, Dijkema et al. (2000) argued that even some of the preferred management methods, often produce some hazardous materials such as incineration residues. Nevertheless, the tourism sector should not be ignored about food waste (Pirani and Arafat, 2014, p. 322), but it is seen that there is a lack of comprehensive studies regarding both determining the quantities of food waste and the reasons that constitute food waste and urgent measures to be taken in this sector (Marthinsen, Kaysen and Kirkevaag, 2012, p. 15). Vergara \& Tchobanoglous (2012) reported that proper planning and control is required in order to prevent the negative impact of waste on the environment. As a result, Ghiani et al. (2014) added that, a proper organization of solid waste management has become an essential task needed to safeguard the environment. Municipal Solid Waste Manual (2000) states that Composting of hotel food waste is one of the best way to manage it. Compost is a perfect soil conditioner. Vikas Mohan (2017) stated that hotels do require commitment of the management and staffs to manage their waste they need to spare time out to work and implement waste management strategies.

\section{Effects of Food Waste}

Most developed countries passed through a period when they were developing environmentally. Today, however, most of these countries have effectively addressed much of the health and environmental pollution issues associated with wastes generation (Amasuomo \& Baird, 2016). The unhealthy waste management practices resulted in several outbreaks of epidemics with high death tolls (Tchobanoglous et al, 1993). Also food waste has been reported by many researchers that have economic effects. Most countries lose lots of money on producing these wasted food, Based on the FAO data, the enormous scale of the problem is evident. Around 30\% (about 1.3 billion tons per year) of food production for human consumption is lost or wasted globally (FAO 2017b). Financially, wasted food costs (Municipal waste management cost, over purchasing cost and lost energy cost) American more than \$100 billion annually (Bloom, 2007).

Moreover, World Resources Institute indicates that globally, food worth 1 trillion USD is lost or wasted each year throughout the entire supply chain. Poland occupies the 5 th position in the EU regarding the value of the estimated cost of food waste that amounts to 14 billion EUR (143 billion EUR in the EU, 850 billion EUR worldwide) (Business Insider Polska 2017, Sipiński 2018). Besides the economic effect, Greenpeace Polska highlighted the environmental impact, namely waste of water, which amounts to 1.72 billion $\mathrm{m} 3$, and $\mathrm{CO} 2$ emissions, that achieve the level of 22.77 million tons annually (Greenpeace Polska 2017). Reducing food loss and waste might be helpful to improve ecological safety in terms of resources limitations (Kwasek et al. 2016). It is 
believed that food production impacts water quality, soil productivity and attributes about $13 \%$ of the nation's greenhouse gas emissions (EPA, 2012). Furthermore, the social problem of global hunger should be also emphasized. Hunger causes insecurity and this food insecurity can increase the likelihood for an individual to have major health concern. 50 Million American households were food insecure in 2009 (USDA, 2019). According to the FAO data, in the period from 2014 to 2016 there have been nearly 795 million undernourished people in the word, mostly in developing countries (about 98\%) (FAO 2017a) while globalization in certain regions contributed to the occurrence of food overproduction, the statistics indicate that if just $1 / 4$ of the food currently lost or wasted globally could be saved, it would be enough to feed 870 million hungry people in the world (Vaqué 2015).

\section{Opportunities created by food waste}

J Sandaruwani and Gnanapala (2016) Finds that the majority of the hoteliers do notrealize that one of the biggest resource efficiency opportunities lays in the kitchen. Opportunities created by food waste including food charity and donation where by food which is not yet spoiled or left with short time to expire will be given to people who are suffering from hunger instead of letting that food go to waste. According to the U.S. Department of Agriculture (USDA), 50 million Americans, or $14 \%$ of American households, were food insecure in 2009. Donating fresh food not only reduces food reaching landfills, but also feeds those in needs. Also to provide staff trainings on how to manage and reduce food waste so as to save different costs (Lewis et al. 2017). They also suggested that there should be more dialogue and resources to support collaboration between industry and all food rescue organizations.

By employing multiple training strategies will increase the effectiveness (for example, in-person training as well as posted signs).Also consider offering recognition or incentives to staff that help to significantly reduce waste or come up with new strategies to reduce waste (EPA, 2017).Another opportunity of serving food from waste is created by encouraging guests to take only the food they can consume goes a long way in reducing wasted food. Food service managers can be more creative to prepare post informational signs at buffet-style food service venues that encourage customers to take only enough food to match their appetite (EPA, 2017).

After feeding people, the next preferred food waste opportunity is to send food waste to local farmers and others who use food scraps (generally vegetative only) to feed animals. To get started, contact the county agricultural extension office, state veterinarian, or county health department to find out about specific state regulations and to find contact information for farmers (EPA, 2017a). Also composting food and compostable packaging (such as soiled paper and compostable plastics such as PLA) can produce a valuable soil amendment that can be used on-site or sold for agriculture, landscaping, or horticultural purposes (EPA, 2017a). Moreover diverting wasted food to anaerobic digestion can generate renewable energy (biogas) and create a valuable soil amendment. Food service venues can partner with wastewater treatment plants, waste haulers, dairies, or municipalities to process their wasted food off-site at an anaerobic digestion facility (EPA, 2017a). 


\section{Research Methodology}

Research Design

The study was guided by a descriptive type of research design where both desk research and field research were employed. The study used descriptive and exploratory methods towards the exploring of the Opportunities and Challenges in Food Waste Management in Coastal Hotels in Tanzania. The main respondents were representative from selected hotels particularly those in the Food and Beverage departments. The sampled population involved respondents from Dar es Salaam (35 respondents), Tanga (30 respondents) and Zanzibar (35 respondents). Simple and random sampling was used to make a valid sample size of the 100respondents. Data collected were edited to identify and eliminate errors made by respondents. Coding was done to translate question responses into specific categories before being input in the statistical software. Descriptive statistics was used to analyse the data since the researcher is exploring an existing situation on Food Waste Management. The analysis was supported by a Microsoft Excel and SPSS which is a computer application package. Output of the data analysis is presented in tables and figures.

Table 2: Questionnaire Distribution

\begin{tabular}{|l|l|l|l|}
\hline Unity of Analysis & Sample size & Distributed Questionnaires & Collected Questionnaires \\
\hline Dar es Salaam & 35 & 35 & 31 \\
\hline Tanga & 30 & 30 & 24 \\
\hline Zanzibar & 35 & 35 & 29 \\
\hline Total & $\mathbf{1 0 0}$ & $\mathbf{1 0 0}$ & $\mathbf{8 4}$ \\
\hline
\end{tabular}

\section{Results and Discussion}

\section{Respondents' Demographic Profile}

The demographic profile of the respondents as presented in Table 1 below, which indicates that the respondents were mostly females (51\%), with the males forming only (33\%) of the total. Most of the respondents were clerks (44\%), followed by supervisors (27\%) with small number of senior staffs (13\%) and large group of respondents (29\%) being between 30 and 34 years old, (21\%) being between 21 and 24 years old and same percentage of respondents aged between 25 and 29 years old and smallest group(13\%) being above 35 years. The researchers found out that the majority of the Food Waste Management initiatives started from year 2010 onwards with (43\%) while in between year 1990-2000 with (21\%) and lastly was in between year 2000 and 2010 with (20\%). 
INTERNATIONAL JOURNAL OF ACADEMIC RESEARCH IN BUSINESS AND SOCIAL SCIENCES Vol. 9, No. 11, November, 2019, E-ISSN: 2222-6990 @ 2019 HRMARS

Table 1: Demographic of the Respondents

\begin{tabular}{|l|l|l|}
\hline Demographic profile & Item & $\mathbf{N}=\mathbf{( 8 4}, \mathbf{i n} \mathbf{\% )}$ \\
\hline \multirow{5}{*}{ Age } & $21-24$ & 21 \\
\cline { 2 - 3 } & $25-29$ & 21 \\
\cline { 2 - 3 } & $30-34$ & 29 \\
\cline { 2 - 3 } & above 35 & 13 \\
\hline \multirow{4}{*}{ Geb Position } & female & 51 \\
\cline { 2 - 3 } & male & 33 \\
\hline \multirow{5}{*}{ FWM Initiative } & senior staffs & 13 \\
\cline { 2 - 3 } & supervisors & 27 \\
\cline { 2 - 3 } & Clerks & 44 \\
\cline { 2 - 3 } & $1990-2000$ & 21 \\
\cline { 2 - 3 } & $2000-2010$ & 20 \\
\cline { 2 - 3 } & 2010 and above & 43 \\
\hline
\end{tabular}

Table 2: Perceptions Pattern of Food Waste Management in Selected Costal Hotel 
INTERNATIONAL JOURNAL OF ACADEMIC RESEARCH IN BUSINESS AND SOCIAL SCIENCES

Vol. 9, No. 11, November, 2019, E-ISSN: 2222-6990 @ 2019 HRMARS

\begin{tabular}{|c|c|c|c|c|c|}
\hline \multirow[t]{2}{*}{ Variable } & \multirow[t]{2}{*}{ Explanation } & \multicolumn{4}{|c|}{ Observation } \\
\hline & & \multicolumn{2}{|l|}{ Tanga } & Dar es Salaam & bar ${ }^{\text {Zanzi }}$ \\
\hline \multirow{2}{*}{$\begin{array}{l}\text { Sources of } \\
\text { Food Wastes } \\
\text { by gender }\end{array}$} & Male & \multicolumn{2}{|l|}{19} & 23 & 15 \\
\hline & Female & \multicolumn{2}{|l|}{5} & 8 & 14 \\
\hline \multirow{2}{*}{$\begin{array}{l}\text { People leave } \\
\text { food most in } \\
\text { Hotels by } \\
\text { gender }\end{array}$} & Male & \multicolumn{2}{|l|}{8} & 11 & 10 \\
\hline & Female & \multicolumn{2}{|l|}{23} & 13 & 19 \\
\hline \multirow[t]{2}{*}{ Variable } & \multirow[t]{2}{*}{ Explanation } & \multicolumn{4}{|c|}{ Observation } \\
\hline & & Yes (N) & Yes (f \%) & No $(N)$ & $\begin{array}{ll} & \text { No (f } \\
\%) & \\
\end{array}$ \\
\hline \multirow{9}{*}{$\begin{array}{l}\text { Origins of food } \\
\text { wastes }\end{array}$} & Quick Service Restaurants & 25 & 30 & 59 & 70 \\
\hline & Residential & 26 & 31 & 58 & 69 \\
\hline & Hotels & 41 & 49 & 43 & 51 \\
\hline & Fast Foods & 36 & 43 & 48 & 57 \\
\hline & Industries & 16 & 19 & 68 & 81 \\
\hline & Grocery Stores & 22 & 26 & 62 & 74 \\
\hline & Event catering & 23 & 27 & 61 & 73 \\
\hline & Cafes, Bars and Discos & 27 & 32 & 57 & 68 \\
\hline & Institutions & 12 & 14 & 72 & 86 \\
\hline \multirow[t]{2}{*}{ Variable } & \multirow[t]{2}{*}{ Explanation } & \multicolumn{4}{|c|}{ Observation } \\
\hline & & Yes (N) & Yes (f \%) & No $(N)$ & \%) ${ }$ No (f \\
\hline \multirow{6}{*}{$\begin{array}{l}\text { Most wasted } \\
\text { foods in Hotels }\end{array}$} & Dairy Products & 36 & 43 & 48 & 57 \\
\hline & Vegetables & 43 & 51 & 41 & 49 \\
\hline & Grain Products & 39 & 46 & 45 & 54 \\
\hline & Fruits & 39 & 46 & 45 & 54 \\
\hline & Sugar/Sweeteners & 29 & 35 & 55 & 65 \\
\hline & Meat, Poultry and Fish & 37 & 44 & 47 & 56 \\
\hline
\end{tabular}


INTERNATIONAL JOURNAL OF ACADEMIC RESEARCH IN BUSINESS AND SOCIAL SCIENCES

Vol. 9, No. 11, November, 2019, E-ISSN: 2222-6990 @ 2019 HRMARS

\begin{tabular}{|c|c|c|c|c|c|c|c|}
\hline & Fats and Oils & 36 & \multicolumn{2}{|l|}{43} & \multicolumn{2}{|l|}{48} & 57 \\
\hline & Eggs & 45 & 53 & & \multicolumn{2}{|l|}{39} & 47 \\
\hline \multirow{5}{*}{\begin{tabular}{l}
\multicolumn{2}{c}{ Motivation } \\
to start Food \\
Waste \\
Management
\end{tabular}} & Company Policy & 48 & \multicolumn{2}{|l|}{57} & \multicolumn{2}{|l|}{36} & 43 \\
\hline & Third party & 41 & \multicolumn{2}{|l|}{49} & \multicolumn{2}{|l|}{43} & 51 \\
\hline & Government requirement & 45 & \multicolumn{2}{|l|}{53} & \multicolumn{2}{|l|}{39} & 47 \\
\hline & Municipal/City council requirement & 39 & \multicolumn{2}{|l|}{47} & \multicolumn{2}{|l|}{45} & 53 \\
\hline & Recycle pre-consumer food & 39 & \multicolumn{2}{|l|}{46} & \multicolumn{2}{|l|}{45} & 54 \\
\hline \multirow[t]{3}{*}{ Variable } & \multirow[t]{3}{*}{ Explanation } & \multicolumn{6}{|c|}{ Observation } \\
\hline & & \multicolumn{2}{|c|}{ Tanga } & \multicolumn{2}{|c|}{ Dar es Salaam } & \multicolumn{2}{|c|}{ Zanzibar } \\
\hline & & $\begin{array}{l}\text { AG } \\
(N / f)\end{array}$ & $\begin{array}{l}\text { DISA } \\
G(N / f)\end{array}$ & $\begin{array}{l}\text { AG } \\
(\mathrm{N} / \mathrm{f})\end{array}$ & $\begin{array}{l}\text { DISA } \\
G(N / f)\end{array}$ & $\begin{array}{l}\text { AG } \\
(\mathrm{N} / \mathrm{f})\end{array}$ & $\begin{array}{l}\text { DISA } \\
G(N / f)\end{array}$ \\
\hline \multirow{11}{*}{$\begin{array}{l}\text { Strategies in } \\
\text { Food Wastes } \\
\text { Management }\end{array}$} & Waste Segregation & $\begin{array}{r}11 \\
(13 \%)\end{array}$ & $\begin{array}{r}73 \\
(87 \%)\end{array}$ & $\begin{array}{r}14 \\
(17 \%)\end{array}$ & $\begin{array}{r}70 \\
(83 \%)\end{array}$ & $\begin{array}{r}9 \\
(11 \%)\end{array}$ & $\begin{array}{r}75 \\
(89 \%)\end{array}$ \\
\hline & $\begin{array}{lll}\text { Following } & \text { National/International } \\
\text { Guidelines }\end{array}$ & $\begin{array}{r}11 \\
(13 \%)\end{array}$ & $\begin{array}{r}73 \\
(87 \%)\end{array}$ & $\begin{array}{c}16 \\
(19 \%)\end{array}$ & $\begin{array}{r}68 \\
(81 \%)\end{array}$ & $\begin{array}{r}15 \\
(18 \%)\end{array}$ & $\begin{array}{r}69 \\
(82 \%)\end{array}$ \\
\hline & Adjustments in Menu & $\begin{array}{r}13 \\
(15 \%) \\
\end{array}$ & $\begin{array}{r}71 \\
(85 \%) \\
\end{array}$ & $\begin{array}{r}16 \\
(19 \%) \\
\end{array}$ & $\begin{array}{r}68 \\
(81 \%) \\
\end{array}$ & $\begin{array}{r}11 \\
(13 \%) \\
\end{array}$ & $\begin{array}{r}73 \\
(87 \%) \\
\end{array}$ \\
\hline & Recycle and Reuse & $\begin{array}{r}12 \\
(14 \%) \\
\end{array}$ & $\begin{array}{r}72 \\
(86 \%)\end{array}$ & $\begin{array}{r}14 \\
(17 \%) \\
\end{array}$ & $\begin{array}{r}70 \\
(83 \%) \\
\end{array}$ & $\begin{array}{r}12 \\
(14 \%)\end{array}$ & $\begin{array}{r}72 \\
(86 \%)\end{array}$ \\
\hline & Separate budget for managing food waste & $\begin{array}{r}13 \\
(15 \%)\end{array}$ & $\begin{array}{r}71 \\
(85 \%) \\
\end{array}$ & $\begin{array}{r}16 \\
(19 \%)\end{array}$ & $\begin{array}{r}68 \\
(81 \%)\end{array}$ & $\begin{array}{r}15 \\
(18 \%) \\
\end{array}$ & $\begin{array}{r}69 \\
(82 \%) \\
\end{array}$ \\
\hline & Staff Training on food waste management & $\begin{array}{r}12 \\
(14 \%) \\
\end{array}$ & $\begin{array}{r}72 \\
(86 \%) \\
\end{array}$ & $\begin{array}{r}15 \\
(18 \%) \\
\end{array}$ & $\begin{array}{r}69 \\
(82 \%) \\
\end{array}$ & $\begin{array}{r}9 \\
(11 \%) \\
\end{array}$ & $\begin{array}{r}75 \\
(89 \%) \\
\end{array}$ \\
\hline & Inventory Control & $\begin{array}{r}16 \\
(19 \%) \\
\end{array}$ & $\begin{array}{r}68 \\
(81 \%) \\
\end{array}$ & $\begin{array}{r}19 \\
(23 \%) \\
\end{array}$ & $\begin{array}{r}65 \\
(77 \%) \\
\end{array}$ & $\begin{array}{r}21 \\
(25 \%) \\
\end{array}$ & $\begin{array}{r}63 \\
(75 \%) \\
\end{array}$ \\
\hline & Preparation/Cooking & $\begin{array}{r}19 \\
(23 \%) \\
\end{array}$ & $\begin{array}{r}65 \\
(77 \%) \\
\end{array}$ & $\begin{array}{r}21 \\
(25 \%) \\
\end{array}$ & $\begin{array}{r}63 \\
(75 \%) \\
\end{array}$ & $\begin{array}{r}9 \\
(11 \%) \\
\end{array}$ & $\begin{array}{r}75 \\
(89 \%) \\
\end{array}$ \\
\hline & Serving at the Counter/Buffet & $\begin{array}{r}14 \\
(17 \%) \\
\end{array}$ & $\begin{array}{r}70 \\
(83 \%) \\
\end{array}$ & $\begin{array}{r}16 \\
(19 \%) \\
\end{array}$ & $\begin{array}{r}68 \\
(81 \%) \\
\end{array}$ & $\begin{array}{r}10 \\
(12 \%) \\
\end{array}$ & $\begin{array}{r}74 \\
(88 \%) \\
\end{array}$ \\
\hline & Customer segregation & $\begin{array}{r}16 \\
(19 \%) \\
\end{array}$ & $\begin{array}{r}68 \\
(81 \%) \\
\end{array}$ & $\begin{array}{r}19 \\
(23 \%) \\
\end{array}$ & $\begin{array}{r}65 \\
(77 \%) \\
\end{array}$ & $\begin{array}{r}19 \\
(23 \%) \\
\end{array}$ & $\begin{array}{r}65 \\
(77 \%) \\
\end{array}$ \\
\hline & $\begin{array}{l}\text { Perception/Attitude/Knowledge of food service } \\
\text { provider }\end{array}$ & $\begin{array}{r}12 \\
(14 \%)\end{array}$ & $\begin{array}{r}72 \\
(86 \%)\end{array}$ & $\begin{array}{r}21 \\
(25 \%) \\
\end{array}$ & $\begin{array}{r}63 \\
(75 \%)\end{array}$ & $\begin{array}{r}17 \\
(20 \%)\end{array}$ & $\begin{array}{r}67 \\
(80 \%)\end{array}$ \\
\hline
\end{tabular}


INTERNATIONAL JOURNAL OF ACADEMIC RESEARCH IN BUSINESS AND SOCIAL SCIENCES

Vol. 9, No. 11, November, 2019, E-ISSN: 2222-6990 @ 2019 HRMARS

\begin{tabular}{|c|c|c|c|c|c|c|c|}
\hline \multirow{3}{*}{$\begin{array}{l}\text { Barriers } \begin{array}{r}\text { to } \\
\text { reduce } \\
\text { wastes }\end{array} \\
\text { food }\end{array}$} & Individual behavior and other factors & $\begin{array}{r}15 \\
(18 \%)\end{array}$ & $\begin{array}{r}69 \\
(82 \%)\end{array}$ & $\begin{array}{r}19 \\
(23 \%)\end{array}$ & $\begin{array}{r}65 \\
(77 \%)\end{array}$ & $\begin{array}{r}20 \\
(24 \%)\end{array}$ & $\begin{array}{r}64 \\
(76 \%)\end{array}$ \\
\hline & Business Model of Hotels & $\begin{array}{r}16 \\
(19 \%)\end{array}$ & $\begin{array}{r}68 \\
(81 \%) \\
\end{array}$ & $\begin{array}{r}20 \\
(24 \%) \\
\end{array}$ & $\begin{array}{r}64 \\
(76 \%) \\
\end{array}$ & $\begin{array}{r}22 \\
(26 \%) \\
\end{array}$ & $\begin{array}{r}62 \\
(74 \%) \\
\end{array}$ \\
\hline & Attitudes and Motivations of hotel staff & $\begin{array}{r}15 \\
(18 \%)\end{array}$ & $\begin{array}{r}69 \\
(82 \%)\end{array}$ & $7 \%)^{23(2}$ & $\begin{array}{r}61 \\
(73 \%)\end{array}$ & $\begin{array}{r}18 \\
(21 \%)\end{array}$ & $\begin{array}{r}66 \\
(79 \%)\end{array}$ \\
\hline \multirow{5}{*}{\begin{tabular}{l}
\multicolumn{2}{r}{ Opportuniti } \\
es of Food \\
Waste
\end{tabular}} & Donation & $\begin{array}{r}15 \\
(18 \%)\end{array}$ & $\begin{array}{r}69 \\
(82 \%)\end{array}$ & $\begin{array}{r}19 \\
(23 \%)\end{array}$ & $\begin{array}{r}65 \\
(77 \%)\end{array}$ & $\begin{array}{r}22 \\
(26 \%)\end{array}$ & $\begin{array}{r}62 \\
(74 \%)\end{array}$ \\
\hline & Animal Feeds & $\begin{array}{r}7 \\
(8 \%) \\
\end{array}$ & $\begin{array}{r}77 \\
(92 \%) \\
\end{array}$ & $\begin{array}{r}17 \\
(20 \%) \\
\end{array}$ & $\begin{array}{r}67 \\
(80 \%) \\
\end{array}$ & $\begin{array}{r}23 \\
(27 \%) \\
\end{array}$ & $\begin{array}{r}61 \\
(73 \%) \\
\end{array}$ \\
\hline & Gasification & $\begin{array}{r}19 \\
(23 \%) \\
\end{array}$ & $\begin{array}{r}65 \\
(77 \%) \\
\end{array}$ & $\begin{array}{r}25 \\
(30 \%) \\
\end{array}$ & $\begin{array}{r}59 \\
(70 \%) \\
\end{array}$ & $\begin{array}{r}19 \\
(23 \%) \\
\end{array}$ & $\begin{array}{r}65 \\
(77 \%) \\
\end{array}$ \\
\hline & Composting & $\begin{array}{r}20 \\
(24 \%) \\
\end{array}$ & $\begin{array}{r}64 \\
(76 \%)\end{array}$ & $\begin{array}{r}22 \\
(26 \%) \\
\end{array}$ & $\begin{array}{r}62 \\
(74 \%)\end{array}$ & $\begin{array}{r}23 \\
(27 \%) \\
\end{array}$ & $\begin{array}{r}61 \\
(73 \%)\end{array}$ \\
\hline & Recycling & $\%)^{11(13}$ & $\begin{array}{r}73 \\
(87 \%)\end{array}$ & $\begin{array}{r}21 \\
(25 \%)\end{array}$ & $\begin{array}{r}63 \\
(75 \%)\end{array}$ & $\begin{array}{c}19 \\
(23 \%)\end{array}$ & $\begin{array}{r}65 \\
(77 \%)\end{array}$ \\
\hline \multirow{6}{*}{$\begin{array}{l}\text { Reasons for } \\
\text { people to leave } \\
\text { food in hotels }\end{array}$} & Large food portion size & $\begin{array}{r}9 \\
(11 \%)\end{array}$ & $\begin{array}{r}75 \\
(89 \%)\end{array}$ & $\begin{array}{r}14 \\
(17 \%)\end{array}$ & $\begin{array}{r}70 \\
(83 \%)\end{array}$ & $\begin{array}{r}19 \\
(23 \%)\end{array}$ & $\begin{array}{r}65 \\
(77 \%)\end{array}$ \\
\hline & Selective eaters & $\begin{array}{r}12 \\
(14 \%)\end{array}$ & $\begin{array}{r}72 \\
(86 \%)\end{array}$ & $\begin{array}{r}16 \\
(19 \%)\end{array}$ & $\begin{array}{r}68 \\
(81 \%)\end{array}$ & $\begin{array}{r}15 \\
(18 \%)\end{array}$ & $\begin{array}{r}69 \\
(82 \%)\end{array}$ \\
\hline & Health conscious & $\begin{array}{r}11 \\
(13 \%)\end{array}$ & $\begin{array}{r}73 \\
(87 \%)\end{array}$ & $\begin{array}{r}20 \\
(24 \%)\end{array}$ & $\begin{array}{r}64 \\
(76 \%)\end{array}$ & $\begin{array}{r}12 \\
(14 \%)\end{array}$ & $\begin{array}{r}72 \\
(86 \%)\end{array}$ \\
\hline & Customer expectations & $\begin{array}{r}15 \\
(18 \%)\end{array}$ & $\begin{array}{r}69 \\
(82 \%)\end{array}$ & $\begin{array}{r}11 \\
(13 \%)\end{array}$ & $\begin{array}{r}73 \\
(87 \%)\end{array}$ & $\begin{array}{r}21 \\
(25 \%)\end{array}$ & $\begin{array}{r}63 \\
(75 \%)\end{array}$ \\
\hline & Customer social norms & $\%)^{11(13}$ & $\begin{array}{r}73 \\
(87 \%) \\
\end{array}$ & $\begin{array}{r}14 \\
(17 \%) \\
\end{array}$ & $\begin{array}{r}70 \\
(83 \%) \\
\end{array}$ & $\begin{array}{r}13 \\
(15 \%)\end{array}$ & $\begin{array}{r}71 \\
(85 \%)\end{array}$ \\
\hline & No reason & $\begin{array}{r}15 \\
(18 \%)\end{array}$ & $\begin{array}{r}69 \\
(82 \%)\end{array}$ & $\begin{array}{r}10 \\
(12 \%)\end{array}$ & $\begin{array}{r}74 \\
(88 \%)\end{array}$ & $\begin{array}{r}21 \\
(25 \%)\end{array}$ & $\begin{array}{r}63 \\
(75 \%)\end{array}$ \\
\hline
\end{tabular}




\section{Status of Food Waste Management in Coastal Hotels}

From this study, it has been found that male customers eat the most in hotels as compared to female customers. On the contrary, even though male customers eat the most in hotels, it is only the female customers who leave food in all locations in Dar es Salaam, Tanga and Zanzibar This study has found that hotels are the main sources of food wastes among other sources including quick service restaurants, fast food services, residential and industrial which includes vegetables having a significant percentage of wastes. Others include dairy Products, grain products, fruits, sugar/sweeteners and meat, poultry and fish.

The study indicates that coastal hotels in Dar es Salaam, Tanga and Zanzibar practice food waste management because of the five factors. Most respondents revealed that it is the hotel policy that motivates hotels to adopt the food waste management practices followed by government requirement for these hotels to adopt waste management. Findings from this study also show that coastal hotels adopt food waste management practices because municipal councils/city council enforces them to do it. This is from the fact that all waste management is being undertaken by the municipal council. This study has also found that food waste management is facilitated more by external factors rather than individual initiatives of hotels. This means that there must be some law enforcement to ensure food waste management is adopted by all hotels. From this study, customers leave food for many reasons in the hotels in all locations of Dar es Salaam, Tanga and Zanzibar. However most respondents disagreed with the fact that leave food mostly due to health conscious i.e watching their weight, Food not meeting customer expectations i.e quality, too old, badly cooked and customer social norms i.e normal to leave a bit of food, don't want to be seen greedy. Most of them leave food with no reasons or whatsoever but just a bad habits which have developed in the society.

As it has been pointed out throughout this study that food wastage is an issue that affects everyone and that it is of concern for businesses in the hospitality and food service sector, it requires effective management. Effective management of food wastes faces several challenges. This study has revealed various factors such as the differences in the number of service locations, type and amount of food discarded and distances from food recycling facilities hotels in a dilemma over how to tackle food waste disposal. Also individual behaviors of these customers as well as most of these hotels' business models are hindering the all process of reducing or eliminating food waste in coastal regions.

Despite the different challenges on food wastes in hotels, there are still some opportunities in food waste management. The study has found that, if food wastes are well managed, they have a positive contribution to respective hotel. Composting can be used as manure and be used in gardens surrounding the hotel compounds. Gasification can be used to leverage power sources for the hotel and therefore reduce costs. Donation can be used a corporate social activity for social activity and donate food to hospitals and schools. Some food wastes can be used as animal feed and some for recycling to make better use of these wasted foods from hotels and create best environment.

\section{Conclusions}

The overall objective for this study is to explore Food Waste Management in Coastal 
Hotels in Tanzania. The findings from this study are expected to provide research facts on why it is important to manage food wastes in hotels in order to utilise various opportunities which have been revealed in this study. The study also is expected to contribute to the expansion of knowledge for food waste management and help them to better deal with the entire waste management to address the issue of environmental sustainability that improves the competitiveness in hotel operations.

However, based on the study objectives, this study has come up with the following conclusions which are explained in the following sections.

Due the fact that female customers leave food mostly in hotels it is therefore concluded that when serving female customers, hotel service providers should be keen in portioning the plate for female customers to avoid food wastes.

Due to the fact that most customers leave food to waste just out of bad attitude without any significant reasons, study concludes that an intensive customer/staff orientation on serving customers should be emphasized by hotels. This will enable staff to understand better the customer needs which in the end may reduce food wastes.

It has also been found that food waste management practices is key in ensuring the business sustainability by leveraging hotel resources in serving customers in a sustainable manner however food waste remains one of the most complicated issues in the hotels since it is caused by various factors and at every stage of the food supply chain. While food waste has so many serious impacts on the environment, finance and society, there are still many obstacles for food service providers when dealing with food waste effective management of food wastes faces several challenges.

It is therefore concluded that if food wastes are well managed, they have a positive contribution to respective hotel. Composting can be used as manure and be used in gardens surrounding the hotel compounds. Gasification can be used to leverage power sources for the hotel and therefore reduce costs. Donation can be used a corporate social activity for social activity and donate food to hospitals and schools so as to protect the whole country from environmental pollution by reducing a big amount of food waste. Through these also society will benefit much at least health wise for those fail to get a meal they will be able to eat and eruption diseases like cholera, malaria and diarrhea will finally be reduced by high percentage because there will be less or no food waste around human environments.

\section{Recommendations}

Food waste management is an important aspect to ensure business sustainability for any business entity. Proper management and administration is required to ensure both internal and external capacities of business entities. The business entities are required to comply with rules and regulations set out by the regulatory authorities on environmental sustainability. For instance in Tanzania, business needs to comply with the National Environmental Management Council (NEMC) standards. To comply with this standard, businesses are required to develop internal environmental management action plans that guide the implementation and integration of all activities. 
Since this study has highlighted the various opportunities for food waste management in leveraging business resources, it is recommended that businesses including coastal hotels to tap this opportunity.

In summary, the following are some of the recommendations to the business entities;

- Businesses to adhere to environmental regulations and to adopt policies and practices to minimize negative environmental impact that might be resulted from poor management of food wastes.

- Organize environmental training to all staffs by putting more emphasis to those that are working in departments that are sources of food wastes. Trainings may include practical exposure to experiences on environmental sustainability most significant change stories.

- Hotels should ensure they invest in environmental sustainability infrastructures. This may include purchase of bins to segregate food wastes. Segregation of food wastes will enable the efficient use of these wastes as highlighted in this study. Some of the opportunities may include composting, land filling, animal feeding and donation.

- Hotels should design and employ innovations in using food wastes to generate biogas. Biogas may leverage power costs and therefore reduce utility costs for the hotel. There are existing technologies in the market that can be used to tap biogas from food wastes. Bio gas may be used for water heating purposes etc.

Thus the government of Tanzania is recommended to supervise its environments in general to ensure that pollution including one which caused by wasting foods is reduced or totally eliminated by enforcing laws, rules and regulations regarding environmental pollutions. Applications of necessary solutions should be seriously practiced and if possible changes of laws and high punishment should be introduced. This will contribute a lot of changes economically and socially national wide, and make Tanzania the best place to live for everyone.

\section{Reference}

Agamuthu P., \& Nagendran P., (2007). Waste management challenges in sustainable development of islands. Retrieved

From http://www.iswa.org/uploads/tx_iswaknowledgebase/Pariatamby.pdf

Amasuomo, E., \& Baird, J. (2016). Solid Waste Management Trends in Nigeria. Journal of Management and Sustainability, 6(4), 35. https://doi.org/10.5539/jms.v6n4p35

Baldwin, C., \& Shakman, A., (2012). Food Waste Management in Greening Food and Beverage Services: A Green Seal Guide to Transforming the Industry. Washington D.C.: Green Seal Inc., pp. 57-58.

Basu, R. (2009). Solid Waste Management-A Model Study. Sies Journal of Management, 6, 20-24. Bergqvist, H., Dutko, I., \& Marinelli, M. (2006). Comparison of the MSW Composition and Collection in Lviv, Perugia and Stockholm. Available at www.ima.kth.se/im/3c1351/Text/Grp1rep_1.doc, accessed at 2006-12-31 
INTERNATIONAL JOURNAL OF ACADEMIC RESEARCH IN BUSINESS AND SOCIAL SCIENCES

Vol. 9, No. 11, November, 2019, E-ISSN: 2222-6990 @ 2019 HRMARS

Berry, S., Beatty, W., \& Klesges, R., (1985). Sensory and social influences on ice cream consumption by males and females in a laboratory setting. Appetite, 6:41-45.

Bruns-Smith, A., Choy, V., Chong, H. \& Verma, R. (2015). Environmental sustainability in the hospitality industry: Best practices, guest participation, and customer satisfaction. Cornell Hospitality Report, 15(3):6-16.

Buah, W. K., Cunliffe, A. M., \& Williams, P. T. (2007). Characterization of Products from the Pyrolysis of Municipal Solid Waste. Process Safety \& Environmental Protection, 85(5), 450-457. https://doi.org/10.1205/psep07024 Council of Ministers.

Cuglin, A. M., Petljak, K. \& Naletina, D. (2017). Exploratory Research of Food Waste Generation and Food Waste Prevention in the Hospitality Industry - The Case of Zagreb Restaurants. Exploratory Research of Food Waste Generation and Food Waste Prevent in Hospitality Industry

Curry, R. (2012). The Composition of Waste Disposed of by the UK Hospitality Industry (No. RES093-001). Waste and Resources Action Programme (WRAP), United Kingdom

Darnton, A. (2008). GSR Behaviour Change Knowledge Review. Practical Guide: An overview of behaviour change models and their uses. Available at:

http://www.civilservice.gov.uk/wp-

content/uploads/2011/09/Behaviourchange_practical_guide_tcm6-9696.pdf (accessed 13 March 2012).

Demirbas, A. (2011). Waste management, waste resource facilities and waste conversion processes. Energy Conversion \& Management, 52(2), 1280-1287.

https://doi.org/10.1016/j.enconman.2010.09.025

Dijkema, G. P. J., Reuter, M. A., \& Verhoef, E. V. (2000). A new paradigm for waste management. Waste Management, 20(8), 633-638. https://doi.org/10.1016/S0956-053X(00)00052-0

Dixon, N., \& Jones, D. R. V. (2005). Engineering properties of municipal solid waste. Geotextiles \& Geomembranes, 23(3), 205-233. https://doi.org/10.1016/j.geotexmem.2004.11.002

FAO, (2014). Definitional framework of Food Loss, FAO, Rome. Available on the Internet:http://www.fao.org/fileadmin/user_upload/savefood/PDF/FLW_Definition_an d_Scope_2014pdf (04/28/2018).

FAO, (2017a). The State of Food Insecurity and nutrition in the World. FAO, Rome.Available on the Internet: http://www.fao.org/3/a-17695e.pdf(04/28/2018).

FAO, (2017b). Food Loss and Food Waste. Available on the Internet: http://www.fao.org/foodloss-and-foodwaste/en/ (04/28/2018).

FAO, (2014). Definitional framework of Food Loss, FAO, Rome. Available on the Internet:http://www.fao.org/fileadmin/user_upload/savefood/PDF/FLW_Definition_an d_Scope_2014pdf (04/28/2018).

Food Wise Hong Kong (2013). Food waste reduction good practice guide for hotel sector.

Ghiani, G., Laganà, D., Manni, E., Musmanno, R., \& Vigo, D. (2014). Operations research in solid waste management: A survey of strategic and tactical issues. Computers \& Operations Research, 44(4), 22 32.https://doi.org/10.1016/j.cor.2013.10.006 
Griffith, C., Jackson, L., \& Lues, R. (2017). The food safety culture in a large South African food service complex: Perspectives on a case study. British Food Journal, 119:729-743

Gunders D. (2012), Wasted: How America Is Losing Up to 40 Percent of Its Food from Farm to Fork to Landfill, Natural Resources Defense Council. http://www.nrdc.org/food/files/wasted-food-IP.pdf

Herman, C. P., \& Polivy, J. (1984). A boundary model for the regulation of eating. In A. J. Stunkard \& E. Stellar (Eds.), Eating and its disorders (pp. 141-156). New York: Raven

Sandaruwani, J. A. R. C., \& Gnanapala, W. K. A. C. (2016). Food wastage and its impacts on sustainable business operations: a study on Sri Lankan tourist hotels.

Procedia Food Science, 6(2015), 133-135.

Kaseva, M. E., \& Gupta, S. K. (1996). Recycling-an environmentally friendly and income generating activity towards sustainable solid waste management. Case study-Dar es Salaam City, Tanzania. Resources Conservation \& Recycling, 17(4), 299-309. https://doi.org/10.1016/S0921-3449(96)01153-6

Kwasek M., Borowski M., Kowalewska M., \& Obiedzińska A. (2016). Z badań nadrolnictwem społecznie zrównoważonym (37). Analiza strat i marnotrawstwa żywności na świecie i w Polsce. Raport PW2015-2019 nr 37 [From the research on socially sustainable agriculture (37). The analysis of food loss and waste in the world and Poland. Report PW 2015-2019 No. 37]. Instytut Ekonomiki Rolnictwa i Gospodarki Żywnościowej - PIB, Warszawa, 8.

Lipinski, B., Hanson, C., Lomax, J., Kitinoja, L., Waite, R., \& Searchinger T. (2013). Reducing food loss and waste. Washington, DC: World Resources Institute

Marthinsen, J., Sundt, P., Kaysen, O. \& Kirkevaag, K. (2012). Prevention of food waste in restaurants, hotels, canteens and catering. TemaNord, Volume 537, 2012, Nordic Council of Ministers. Available at: http://www.ostfoldforskning.no

Michael-Agwuoke, M. U. (2012). Is waste-to-energy changing the definition of waste? Presented at the 3rd International chemical and environment conference ICEEC 2012, Kuala Lumpur, Malaysia, 21-23 December, 2012

MSW Manual, (2000). Manual on municipal solid waste management. Government of India, Ministry of urban development.

Ocicka, B., \& Raźniewska, M. (2018). Food Waste Reduction as a Challenge in Supply Chains Management, Scientific Journal of Logistics, 14 (4), 549-561

OECD. (2003). Glossary of Statistical Terms: Waste. Retrieved 23 July, 2012, from http://stats.oecd.org/glossary/detail.asp?ID=2896

Omidiani, A., Hashemi Hezaveh, S. M., (2016). Waste Management in Hotel Industry in India: A Review. Int. J. Sci. Res. Publ., 6: 670-680 (11 pages)

Papargyropoulou E., Wright N., Lozano R., Steinberger J., Padfield R., \& Ujang Z, (2016). Conceptual framework for the study of food waste generation and prevention in the hospitality sector, Waste Manage 49(3), 326-336

Parfitt, J., Barthel, M., and Macnaughton S., (2010). Food waste within food supply chains: Quantification and potential for change to 2050-365 pg 306581 10.1098/rstb.2010.0126 Philosophical transactions of the Royal Society of London. Series B, Biological sciences 
Pirani, S. I., \& Arafat, H. A. (2015). Reduction of Food Waste Generation in theHospitalitylndustry. Journal of Cleaner Production.http://doi.org/10.1016/j.jclepro.2 015.07.146 Procedia Food Science, 6-133-135.

Remolador, M. A. (2011). Guide to greening hotels through waste management \& green purchasing. Northeast Recycling Council (NERC) results of a survey among employees of two European research centers in Italy and Germany. Sustainability, 7(3):2695-2715.

Sandaruwani, J. A. R. C., \& Gnanapala, W. K. A. C. (2016). Food wastage and its impacts on sustainable business operations: a study on Sri Lankan tourist hotels. sector.

Shakman, A., (2013). How to Cut Pre-Consumer Food Waste. [Online] URL:http://www.foodmanagement.com/facilities-management/how-cut-pre-consumer-food-waste

Singh, Dr \&, Amandeep, Ad. (2018) Food Waste Management: Study of Indian Hotel Industry 10.13140/RG.2.2.15908.37760

Sipiński D., (2018). Lost calories: How to successfully combat food waste, Polityka Insight, 5.

Tchobanoglous, G., Theisen, H., \& Vigil, S. (1993). Integrated Solid Waste Management: Engineering Principles and Management Issues. Water Science \& Technology Library, 8(1), 63-90.

Troschinetz, A. M., \& Mihelcic, J. R. (2009). Sustainable recycling of municipal solid waste in developing countries. Waste Management, 29(2), 915-923. https://doi.org/10.1016/j.wasman.2008.04.016

Vaqué L. G., (2015). Food Loss and Waste in the European Union: A New Challenge for the Food Law? 20-33.

Vergara, S. E., \& Tchobanoglous, G. (2012). Municipal Solid Waste and the Environment: A Global Perspective. Environment and Resources, 37(37), 277-309. https://doi.org/10.1146/annurev-environ-050511-122532

Mohan, V., Deepak, B., Sharma M., (2017). Reduction and management of waste in Hotel Industry. International journal of engineering research and application, Vol 7 issue 7 pp3437.

White, P. R, Franke, M., \& Hindle, P. (1995). Integrated Solid Waste Management: A Lifecycle Inventory. Berlin: Springer.

White, P. R., Franke, M., \& Hindle, P. (1995). Integrated Solid Waste Management: A Lifecycle Inventory. Berlin: Springer.

World Population Review. Available online: http://worldpopulationreview.com/world-cities/dares-salaampopulation/ (accessed on 20 November 2018).

WRAP. (2011) applying the waste hierarchy: A guide to business. Retrieved from http://www.fccenvironment.co.uk/assets/files/pdf/content/wrap-applying wastehierarchy.pdf 